\title{
IS THERE A RIGHT TO ARCHITECTURE?
}

\author{
Thomas FISHER \\ University of Minnesota, 89 Church Street SE, Minneapolis, Minnesota, USA \\ E-mail: tfisher@umn.edu
}

Received 15 April 2014; accepted 18 September 2014

\begin{abstract}
Architecture, defined here most broadly as human shelter, addresses basic human needs of safety, security, privacy, and protection from the elements, but it is often viewed not as a right that every person has, but as a vehicle for controlling people, stimulating investment, and a range of other social, political, and economic interests. This article looks at the ethics of this situation from various ethical perspectives and concludes that, regardless of one's point of view, every human being has a right to shelter.
\end{abstract}

Keywords: shelter, needs, ethics, rights.

\section{Introduction}

What obligation do we have to protect people from the elements, provide for their basic needs, and promote their well-being and sense of belonging to a community of other people. Do people, in other words, have a right to shelter? To answer that question, let's begin with the shelter part. Archeological and anthropological evidence shows that human beings have always had the ability to construct shelter for themselves. Obviously some people will have greater skill at this than others, but every human community has possessed the ability to shelter itself, just as we have long had the ability to feed and clothe ourselves. If we didn't, we would not have lasted long as a species, and so securing shelter for ourselves remains a core capacity of what it means to be human.

Indeed, when we look at the diversity of shelter that humans have evolved over many thousands of years, we can only marvel at its sophistication: its cultural appropriateness and climate responsiveness. And the fact that we largely built such shelter with what we have had at hand and have left almost no trace of it behind speaks to the superiority of indigenous shelter to much of what we build today.

For further evidence of our ability to secure shelter, we have only to look at the millions of people living in informal settlements in cities around the world.
Drawn by economic opportunity - or pushed by rural poverty - the residents of these favelas, barrios, and slums - their very names evocative of the dismissal of them on the part of the formal economy - have shown great initiative and imagination in the use and reuse of the materials at hand in creating shelter for themselves and their families.

We should not romanticize these environments. As Katherine Boo shows in her book Behind the Beautiful Forevers, life in the "undercity" of a Mumbai slum remains extremely difficult for the people living there (Boo 2012). But what remains most inhuman about these places is not so much the shelter itself, but the lack of basic infrastructure - clean water, adequate sanitation, and safe power - as well as the lack of ownership of the land, which makes life there so tenuous.

We all depend upon governments and non-government organizations to provide the infrastructure and the legal frameworks that allow us to occupy land in a safe and sanitary way, something rarely provided to the residents of informal settlements. That has made the provision of "sites and services" by entities like The World Bank an important strategy in such communities, ensuring stable land tenure and dependable infrastructure upon which people can build shelter for themselves (Mayo, Gross 1987). The 
failure of many governments to provide such things in informal settlements brings us to what we mean by the word "right".

\section{Property rights and wrongs}

Most governments will say that squatters "have no right" to settle on the land that they do. People may have the ability to construct shelter for themselves, but where they build it becomes a matter of property rights, the withholding of which becomes the way in which those in power control those without power. Indeed, the image so often seen in global cities of informal settlements pushing right up against formal - and frequently quite expensive - housing makes this conflict between those who have a "right" to their property and those who have no such "right" all too visible.

John Locke once wrote: "There can be no injury, where there is no property" (Locke 1952). And so one way to deal with the inequalities and "injuries" that come from owning or not owning property involves the dissolution of private property itself, something that utopian writers have envisioned as far back as Plato. This seems unlikely in a world dominated by capitalistic thinking, which upholds private property rights as almost sacrosanct. But the rise of informal economies - which, according to the World Bank, amount to between $25 \%$ and $40 \%$ of the annual economic activity in developing countries in Asia and Africa - suggests that another option has already taken hold: people building their shelter on whatever land they can, regardless of who owns it (World Bank 2014).

We often see the rise of informal settlements and the informal economies they depend on as a sign of impoverishment, but it may also signal something else: the decline of the nation state and the ineffectiveness of central governments in controlling what ordinary people will do to meet their needs. The people living in such informal communities may not have the "right" to be there, but they do have the "responsibility" to take care of themselves and their families and they have taken on that responsibility with great energy and often a lot of imagination.

Even asking the question of whether people have a right to shelter reveals a terrible skew in how we think about and organize our world. Of course people have a right to protection from the elements; unlike other animals, humans cannot live for every long out-ofdoors and so denying the right to shelter constitutes the denial of what makes us human, something that no one has the right to do. Even criminals who commit the most heinous crimes against humanity still have the right to shelter in the form of a prison cell. That we even ask the question of whether such a right exists suggests that we have somehow lost touch with some fundamental aspects of our humanity.

The question also shows that we don't understand a fundamental paradox: that best way to help oneself is to help others. Or put another way, we only hurt ourselves - economically as well as psychologically when we refuse to help those in need of something so basic as shelter. Research has shown, for example, that people who live in mixed income communities have better health outcomes than when they live in uniformly poor neighborhoods. Wealthier communities may think that they are protecting their real estate values by forbidding "affordable" housing, but the well-to-do in those communities ultimately pay a much higher price for two reasons. First, mixed income neighborhoods have, on average, higher real estate values than those with all on one kind of property and second, we all pay for higher healthcare costs in terms of higher premiums and co-pays when a sizable segment of the population has poorer health. By disassociating costs and keeping different areas of human activity artificially separated, we end up making costly - and foolish - mistakes that harm ourselves as well as others in the process.

\section{Design in the Hierarchy of Needs}

These costly errors come from our organizing modern societies in ways that cause us to remain stuck on the first two levels of Abraham Maslow's Hierarchy of Needs (Maslow 2011). Those first two levels involve the securing of basic needs like food, water, warmth, security, stability, and freedom from fear, and as Maslow argued, we cannot satisfy higher-order needs like a sense of belonging (Maslow's third level), self-esteem (fourth level), and self-actualization (fifth level) if we remain constantly worried about or preoccupied with the needs of level one and two. Poor people, of course, face this dilemma, unable to fulfill their higher order needs because they do not know where their next meal will come from or whether they will be safe when they next leave their house.

But first and second order needs seem to preoccupy almost everyone in our commercial culture, rich and poor. By focusing our attention on what we desire rather than what we need, commerce has made the quality of our (often imported) food, the convenience of our (often bottled) water, the ubiquity of our (often fossil-fueled) warmth, and the invincibility of our (of- 
ten electronic) security so much of an issue that people work long hours and aspire to high-paying jobs so that they can afford luxury versions of the most basic needs, and end up having no more time than the poor for activities that lead to self-actualization.

Maslow does not list shelter in his Hierarchy of Needs, although warmth, security, and stability seem clearly related to having a home. And this also seems clearly a part of the higher order needs, involving a sense of belonging, of self-esteem, and self-actualization. A human life without shelter and a community of some sort is, in a fundamental sense, not a human life. So why do we need to even ask if there is a "right" to shelter? Because some use the withholding of shelter as a way of controlling or defeating others, such as efforts on the part of dictators in countries like Libya and Syria to remove rebels by leveling the buildings and settlements they inhabit or efforts on the part of warring tribes in places like Rwanda or Darfur to engage in ethnic cleansing through the elimination of entire neighborhoods or villages. The withholding of shelter through violence becomes a way of dehumanizing enemies.

Which leads us to ask, as we deal with homelessness in the United States, what motivates our withholding of shelter for every one of our citizens. Does this constitute our own form of economic cleansing, our own violence against those who suffer from mental illness, addiction, or simply bad luck? Do we so fear such possibilities in our own lives that we would rather the homeless simply go away rather than deal with their lack of shelter? Does the question of the "right" to shelter say more about those who would deny that right than it does about anything else?

The denial of a right so basic to human well being as shelter ultimately raises the most fundamental question about ethics: does anyone - from the most embattled dictator to the most hardline capitalist have the right to deny others such a right? In the West, there comprise four, fundamentally different approaches to answering the question of rights. And, as I would argue, all four lead us to the same conclusion along a different path.

In terms of virtue ethics, it takes but a second of reflection to realize that those who would withhold the right of others to have at least a minimum of shelter are not fair, just, or prudent. All human beings have a right to have their most basic needs met and any society that would deny that right undermines the very basis upon which human societies have any role at all. Nor is such denial prudent since a population without shelter quickly becomes a population that will seek to overthrow those who would deny such a basic need. Here, architects and the design community generally has a central part to play in not only the design of housing, but the revealing of what happens when such housing is denied.

Social contract ethics leads us to a similar conclusion. This ethics holds that all societies have a "contract" with its people to meet their needs, and while different societies meet this contract in different ways, ranging from central authoritarian governments to minimal, laissez-faire ones, all societies have - as Hobbes and Rousseau both argued - a contractual responsibility to ensure some degree of shelter for its people. Violation of that social contract, again, becomes a reason to overthrow those in power and to establish a new government that meets its contractual obligations. Architects and designers, too, remain a part of that social contract and a professional obligation to enable people to have access to shelter equals the obligation of medical professionals that people have access to health or of legal professionals, that they have access to justice.

Duty ethics takes a more reciprocal path to the same point. Kant argued not only that we should treat others as ends and not means to our ends, but also that we should act as if everything we did were to become universal. With that categorical imperative in mind, clearly the absence of shelter by even a few cannot obviously become a universal, since it would mean that we would accept the absence of shelter by all. So, unless we are all willing to be without shelter itself hardly something any person would want - we cannot let any one of us be without it. Here, too, professional duty comes into play. Architects and designers cannot provide architecture for a few without assuming some responsibility for ensuring that all people have at least the minimal shelter available to them. In other words, the design community has as much of an obligation to the poorest among us as to the wealthiest who can pay design fees, and anything less than that represents an absolute abrogation of professional duty.

Finally, consequentialist ethics takes us on yet another path to the same end. It argues that we should attend to the greatest good for the greatest number, a utilitarian calculus that forces us to ask what the greatest number of people need and what actions would lead to their greatest good. While such a calculus can lead some to argue that as long as the greatest number of us has shelter, we need not concern ourselves with the minority that don't, but that misunderstands the consequences of such thinking. The greatest good has to include the need of all people to have access to shelter and the greatest number - all people, in other words - have a right to that good. 


\section{Conclusion}

This analysis suggests that, whichever ethical system one adheres to, we can only draw one conclusion: that all people have a right to shelter and that that right is a fundamental aspect of being human. The denial of that right or the creation of conditions that render people homeless also represents one of the most basic ethical violations, whatever the reason for it. Anyone who would deny that such a right exists is, in the end, simply wrong.

\section{References:}

Boo, K. 2012. Behind the beautiful forevers: life, death, and hope in a Mumbai undercity. New York: Random House.

Locke, J. 1952. On property, in Second treatise of civil government. Chicago: The University of Chicago Press.

Maslow, A. H. 1943. A Theory of Human Motivation, Psychological Review 50: 370-396. Washington, DC: American Psychological Association. http://dx.doi.org/10.1037/h0054346

Mayo, S. K.; Gross, D. J. 1987. Sites and services - and subsidies: the economics of low-cost housing in developing countries, The World Bank Economic Review 1(2): 301-335. http://dx.doi.org/10.1093/wber/1.2.301

World Bank. 2014. Workers in the informal economy, Labor Markets [online], [1 April 2014]. Available from Internet: http://web.worldbank.org/WBSITE/EXTERNAL/TOPICS/ EXTSOCIALPROTECTION/EXTLM/0,,contentMDK:202 24904 menuPK:584866 pagePK:148956 piPK:216618 th eSitePK:390615,00.html

\section{THOMAS FISHER}

University of Minnesota, 89 Church Street SE, Minneapolis, Minnesota, USA.E-mail: tfisher@umn.edu

Thomas Fisher is a Professor in the School of Architecture and Dean of the College of Design at the University of Minnesota. A graduate of Cornell University and Case Western Reserve University, he has written or co-authored 9 books, over 50 book chapters or introductions, and over 325 articles in professional journals and major publications. His current research interests involve system design and resiliency. 